Jurnal Ilmiah "Kreatif" Vol. 18 No. 1, Januari 2020

"Jurnal Studi Pemikiran Pendidikan Agama Islam"

\title{
POTRET IDEOLOGI PENDIDIKAN DALAM PENANAMAN NILAI KEISLAMANDI SDIT IMAM SYAFI'IY KOTA BIMA
}

\author{
Oleh: \\ Agus Gunawan, Abdussahid, Husnatul Mahmudah \\ Institut Agama Islam (IAI) Muhammadiyah Bima \\ agusaladzimm1996@gmail.comabdussahid1@gmail.comarraynez@gmail.com
}

\begin{abstract}
Abstrak:
Penelitian ini dilakukan di SDIT Imam Syafi'iy Kota Bima dengan tujuan untuk mengetahui nilai-nilai keislaman yang ditanamkan pada siswa dan ideologi pendidika apa yang diterapkan di SDIT Imam Syafi'iy Kota Bima. Ideologi pendidikan yang diterapkan dapat mempengaruhi proses pendidikan yang berlangsung sehingga dapat pula memengaruhi output/hasil pendidikan tersebut. Penelitian ini berangkat dari realita disekolah umum dan sekolah Islam dalam menanamkan nilai-nilai keislaman pada siswa, mengunakan cara, teknik, atau ideologi yang berbeda. Hal ini berpengaruh pada pola atau pilihan ideologi pendidikan yang dipakai di sekolah tersebut. Penelitian ini merupakan penelitian kualitatif dengan menguraikan persoalan secara naratif deskriptif. Pengumpulan data dilakukan dengan mengadakan observasi, wawancara, dan dokumentasi. Analisis data dilakukan dengan analisis kualitatif, adapun pemeriksaan keabsahan data dilakukan dengan mengadakan trigulasi. Hasil penelitian meliputi: (1). Nilai-nilai keislaman yang ditanamkan di SDIT Imam Syafi'iy Kota Bima yaitu: a. niali aqidah, b. nilai ibadah/syariah, c. nilai akhlak. (2). Ideologi pendidikan yang digunakan dalam menanamkan nilainilai keislaman di SDIT Imam Syafi'iy Kota Bima. SDIT Imam Syafi'iy dalam menanamkan nilai-nilai keislaman pada peserta didik menggunakan ideologi pendidikan konservatisme.
\end{abstract}

Kata Kunci: Ideologi, Pendidikan, Islam, SDIT, Nilai Keislaman

\section{Pendahuluan}

Penanaman nilai-nilai keislaman disamping sebagai upaya, proses, usaha mendidik murid untuk memahami atau mengetahui juga sekaligus menghayati dan mengamalkan nilai-nilai Islam. Anak mempunyai potensi sejak lahir yang sangat memungkinkan untuk ditumbuh kembangkan dan dipupuk dengan nilai-nilai keislaman sejak dini. Dimana ilmu dan iman menjadi sumber orisinil pendidikan Islam yang 
Jurnal Ilmiah "Kreatif" Vol. 18 No. 1, Januari 2020 "Jurnal Studi Pemikiran Pendidikan Agama Islam"

sejalan dengan tuntutan kehidupan modern sekarang ini. Jika sistem pendidikan tidak berlandaskan iman dan ilmu maka tidak akan mampu merealisasikan kebahagian hidup manusia yang sempurna.Tujuan akhir pendidikan Islam yakni meraih keridhohan Allah SWT, atau meraih kebahagiaan/kebaikan dunia dan akhirat. Tujuan tersebut substansinya tidak berbeda dengan maksud keberadaan manusia itu sendiri di dunia ini. Sebab subyek didik adalah manusia yang akan meraih tujuan yang dimaksud. $^{1}$

Pendidikan diyakini dapat menjadi solusi berbagai macam problem sosial yang terjadi dimasyarakat. Sehingga dalam pelaksanaannya, pendidikan didesain untuk mencapai tujuan tertentu sesuai dengan yang diinginkan oleh pelaku kepentingan. Di sekolah umum maupun di sekolah Islam pun memiliki tujuan yang berbeda, juga didesain oleh ideologi berbeda pula. Hal ini berpengaruh pada pola atau pilihan metode pendidikan yang dipakai di sekolah tersebut. Perbedaan arah praktek penyelenggaraan pendidikan pada dasarnya disebabkan oleh perbedaan ideologi. Persoalan ideologi dalam pendidikan terkait dengan sistem nilai atau pola gagasan yang menjadi keyakinan seseorang. Dalam paradigma ini pendidikan agama sebagai sumber nilai lebih menonjolkan fungsi moral spiritual dan afektif daripada kognitif.

Disetiap Sekolah Dasar Islam Terpadu (SDIT), memiliki ciri-ciri khas masing-masing dalam penanaman nilai-nilai keislaman, dalam menanamkan nilai-nilai tersebut menggunakan ideologi pendidikan yang berbeda. Sebagaimana ada 6 model ideologi pendidikan yang dikembangkan oleh Wiliam F. O'Neil yaitu: (1) Ideologi pendidikan fundamentalisme; (2) Ideologi pendidikan intelektualisme; (3) Ideologi pendidikan konservatisme; (4) Ideologi pendidikan liberal; (5) Ideologi pendidikan liberasionisme; (6) Ideologi pendidikan anarkisme. ${ }^{2}$ Penelitian ini hendak menguraikan dari ke 6 ideologi pendidikan di atas ideologi pendidikan yang mana yang digunakan oleh SDIT Imam Syafi'iy dalam menanamkan nilai-nilai keislaman.

\footnotetext{
${ }^{1}$ Suroso Abdussalam, "Sistem Pendidikan Islam”,(Bekasi: sukses Publishing, 2011), 58.

${ }^{2}$ PauloFreire dkk, "Menggugat Pendidikan", (Yogyakarta: Pustaka Pelajar. 2003), 34 .
} 
Jurnal Ilmiah "Kreatif" Vol. 18 No. 1, Januari 2020 "Jurnal Studi Pemikiran Pendidikan Agama Islam"

Penanaman nilai-nilai keislaman pada anak di sekolah, diharapkan setelah mereka tumbuh dewasa nilai-nilai ini akan terus melekat dalam diri siswa dan anak akan selalu melakukan perbuatan baik sesuai dengan yang diperintahkan oleh agama Islam, dan tentunya pengalamanpengalaman pada masa anak-anak merupakan landasan dasar kepribadian seseorang pada saat anak beranjak dewasa. Oleh karena demikian, dalam penelitian ini penulis hendak menganalisis pilihan ideologi pendidikan yang digunakan oleh SDIT Imam Syafi'iy dalam menanamkan nilai-nilai keislaman pada peserta didik dengan menganalisi dua hal diantaranya: 1) Bentuk nilai-nilai keislaman yang ditanamkan di SDIT Imam Syafi'iy Kota Bima., dan 2) Fungsi ideologi pendidikan yang mana yang digunakan dalam menanamkan nilai-nilai keislaman di SDIT Imam Syafi'iy Kota Bima.

\section{Metode Penelitian}

Jenis penelitian ini adalah kualitatif dan sumber data penelitian ini ada dua yaitu sumber data Primer dan sumber data Sekunder. Sumber data primer mencakup Guru dan siswa-siswa di SDIT Imam Syafi'i.Sumber data sekunder mencakup catatan tertulis sepeerti buku, dokumen yang berhubungan penelitian. Dari beberapa sumber data tersebut dapat diperoleh data tentang fungsi ideologi pendidikanyang mana yang digunakan dalam menanamkan nilai-nilai keislaman di SDIT Imam Syafi'iy Kota Bima. Dalam pengumpulan data diusahakan mendapat data seobyektifnya dan menghindari subyektif, dalam pengumpulan data ini hanya melibatkan Guru PAI dan Siswa/siswi di SDIT Imam Syafi'iy Kota Bima. Untuk mempermudah pengumpulan data, ada tiga metode pengumpulan data yang digunakan yaitu observasi, wawancara, dan dokumentasi.

\section{Tinjauan Teoritis}

\section{Ideologi-Ideologi Pendidikan: Pengertian dan Pembagiannya}

Menurut bahasa (etimologi) kata "ideologi" berasal dari dua kata, yaitu: "idea" yang artinya pikiran dan "logos" yang artinya ilmu. Istilah ideologi bisa dimaknai dan mengandung pengertian berarti ilmu pengetahuan tentang ide-ide, tentang keyakinan atau tentang gagasan. Pengertian lainnya, ideologi adalah studi tentang gagasan, pengetahuan kolektif, pemahaman-pemahaman, pendapat-pendapat, nilai-nilai, 
Jurnal Ilmiah "Kreatif" Vol. 18 No. 1, Januari 2020 "Jurnal Studi Pemikiran Pendidikan Agama Islam"

prakonsepsi-prakonsepsi, pengalaman-pengalaman atau ingatan informasi sebuah kebudayaan dan juga rakyat individual. Secara umum dapat dikatakan bahwa, Ideologi sebagai sistem berfikir, sistem kepercayaan, praktik-praktik simbolik yang berhubungan dengan tindakan sosial dan politik. ${ }^{3}$

Sementara filosuf Prancis Antoine Destult de Tracy yang hidup pada masa Revolusi Prancis orang yang pertama kali menemukan istilah "ideology" pada tahun 1796, mendifinisikan ideologi sebagai "ilmu tentang pikiran manusia (sama seperti biologi dan zologi yang merupakan ilmu tentang spesies) yang mampu menunjukan jalan yang benar menuju masa depan". Tilaar berpendapat ideologi merupakan sistem keyakinan yang dianut masyarakat untuk menata dirinya sendiri. ${ }^{4}$

Perkembangan ideologi pendidikan dalam dunia pendidikan hari ini, tidak terlepas dari pemikiran tokoh-tokoh seperti William F. O'Neil dan Paulo Freire yang mencoba meramu beberapa pemikiran tokohtokoh sebelumnya yang bergerak pada tataran filsafat dan logika yang kemudian memasukkan ide-ide sebagai konsep berfilsafat, yang kemudian melahirkan konsep ideologi sebagai bagian disiplin ilmu baru.

Misalnya Soeharto, membagi ideologi pendidikan menjadi 2 (dua) kelompok besar, yaitu; pertama ideologi konservatif yang meliputi ideologi pendidikan fundamentalisme, ideologi pendidikan intelektualisme dan ideologi pendidikan konservatisme. Kedua, ideologi liberal yang meliputi ideologi pendidikan liberalisme, ideologi pendidikan liberasionisme, dan ideologi pendidikan anarkisme. Sementara, Freire dalam pemaparan dan pembahasan secara umum, memetakan ideologi pendidikan tersebut berdasarkan klasifikasi yang dikembangkan William F O’Neil ada 6 (enam) ideologi pendidikan, sebagai berikut. ${ }^{5}$

${ }^{3}$ JohnB. Thomson, "Analisis Ideologi Kritik Wacana Ideologi-ideologi Dunia", (Penerjemah Haqqul Yaqin. Yogyakarta: IRCiSoD. 2007), 17.

${ }^{4}$ H.A.R. Tilaar. "Kekuasaan dan Pendidikan Suatu Tinjauan dar Perspektif Studi Kultural", (Magelang: IndonesiaTera. 2003), 114. 2003), 34.

${ }^{5}$ Paulo Freire dkk, "Menggugat Pendidikan", (Yogyakarta: Pustaka Pelajar. 
Jurnal Ilmiah "Kreatif" Vol. 18 No. 1, Januari 2020 "Jurnal Studi Pemikiran Pendidikan Agama Islam"

a. Ideologi Pendidikan Fundamentalisme

Dalam pemahaman ideologi pendidikan fundamentalisme, masyarakat kontemporer dihadapkan pada keruntuhan moral dalam waktu dekat, dan keharusan tertinggi yang musti dilakukan adalah merombak tolak ukur keyakinan dan perilaku konvensional dengan cara kembali ke ciri-ciri kebaikan yang lebih tinggi di masa silam. Sejalan dengan itu, sasaran pendidikan adalah untuk memulihkan cara-cara yang lebih baik, demi membangun kembali tatanan sosial yang ada. Sekolah seharusnya menekankan karakter moral yang layak, melatih siswa untuk menjadi pribadi yang baik diukur dengan tolak ukur perilaku moral tradisional.

Sekolah mesti memusatkan perhatian pada pembaharuan polapola budaya lama; ia harus membantu siswa untuk menemukan kembali nilai-nilai yang terkandung dalam tradisitradisi budaya yang mendasar, penekanannya harus diberikan pada regenerasi moral, dalam hal membangun kemabali masyarakat menurut jalur-jalur pendekatan tradisional terhadap keyakinan dan perilaku. Menurut William F. O’Neil, sekolah juga mesti menekankan latihan moral dan berbagai jenis keterampilan-keterampilan akademik dan praktis yang diperlukan untuk membantu siswa menjadi anggota yang aktif dalam tatanan sosial yang digenerasikan secara tepat: keterampilanketerampilan belajar yang mendasar, pelatihan pembentukan karakter, pendidikan fisik (termasuk pelajaran kesehatan), sejarah nasional, kesusastraan nasional, pelajaran agama. ${ }^{6}$

b. Ideologi Pendidikan Intelektualisme

Ideologi intelektualisme, menganut sebuah etika diri yang terbuka yang universalistik, dan hampir semua intelektualis cendrung untuk mengajukan sarana pelatihan kecerdasan sebagai sebuah cara yang unggul (yang alamiah) untuk menuntun individu ke arah pencerahan filosofis atau relegius. Sasarannya secara keseluruhan adalah pribadi yang tercerahkan (dan karenanya kesadaran diri) dan individu-individu yang direncanakan inilah yang harus mengendalikan negara, dengan begitu mereka juga mengendalikan

${ }^{6}$ William F. O’Neil. “Ideologi-Ideologi Pendidikan”, (alih bahasa Omin Intan Naomi. Yogyakarta: Pustaka Pelajar. 2002), 247-252. 
Jurnal Ilmiah "Kreatif" Vol. 18 No. 1, Januari 2020 "Jurnal Studi Pemikiran Pendidikan Agama Islam"

proses pendidikan, dan pada gilirannya, pengendalian atas pendidikan pada puncaknya menentukan pencerahan individu-individu lain.

Menurut ideologi intelektualisme, sekolah-sekolah mesti mengadakan pelatihan dan pembinaan untuk membawa setiap orang kepada potensi mereka masing-masing. Mereka yang mencapai profil moral dan intelektual yang ideal harus secara tepat mengambil kendali atas negara. Sekolah, sebagai satu dari sekian agen penting dalam negara, mesti menjamin pendidikan yang tepat bagi semua orang. ${ }^{7}$

c. Ideologi Pendidikan Konservatisme

Bagiideologi pendidikan kaum konservatisme, tujuan dan sasaran pendidikan adalah sebagai pelestarian dan penerusan polapola kemapanan sosial serta tradisi-tradisi. Berciri orientasi masa kini, pendidik konservatif sangat menghormati masa silam, namun mereka lebih memusatkan perhatiannya pada kegunaan dan penerapan pola belajar mengajar di dalam konteks sosial yang ada sekarang.

Ideologi konservatif, pada dasarnya mendukung ketaatan terhadap lembaga-lembaga dan proses-proses budaya yang sudah teruji oleh waktu, disertai dengan rasa hormat yang mendalam terhadap hukum serta tatanan sosial yang berlaku, sebagai landasan bagi perubahan sosial yang konstruktif. Dalam hal pendidikan, kaum konservatisme menganggap bahwa sasaran utama sekoah adalah pelestarian, penerusan struktur, dan sistem sosial serta pola-pola dari tradisi-tradisi yang sudah mapan. Ada dua varian yang mendasari ideologi-ideologi pendidikan konservatisme:

1) Ideologi konservatisme religius, menekankan pelatihan rohani sebagai pusat landasan watak moral yang tepat.

2) Ideologi pendidikan konservatisme sekuler, peduli pada perlunya pelestarian dan penyaluran keyakinan-keyakinan dan praktikpraktik yang ada, sebagai sebuah jalan untuk melestarikan pertahanan hidup secara sosial sekaligus keefektifan sosial. Saat ini, konservatisme relegius paling terwakili dalam orientasi pendidikan tradisi-tradisi protestan, seperti Lutheran dan baptisn; sedangkan yang sekuler diwakili oleh para kritisi yang tajam dari

${ }^{7}$ William F. O’Neil. “Ideologi-Ideologi Pendidikan”...,268-269. 
Jurnal Ilmiah "Kreatif" Vol. 18 No. 1, Januari 2020 "Jurnal Studi Pemikiran Pendidikan Agama Islam"

pendukung progresivisme dan permisivisme pendidikan, seperti pemikiran James Koerner serta Hymen Rickover. ${ }^{8}$

d. Ideologi Pendidikan Liberal

Ideologi pendidikan liberal bertujuan untuk melestarikan dan memperbaiki tatanan sosial yang ada, dengan cara mengajarkan kepada siswa bagaimana caranya menghadapi persoalan-persoalan dalam kehidupannya secara efektif. Karena manusia adalah makhluk sosial yang bersandar pada orang lain untuk bertahan hidup pada masa bayi dan kanak-kanak, dan bergantung pada kondisi-kondisi budaya yang menjamin perilaku yang berhasil baik dalam persaingan antarspesies, maupun dalam persaingan antarmasyarakat dalam spesies (manusia) itu sendiri, atau pun persaingan antarindividu dalam sebuah masyarakat, maka kegiatan belajar secara personal selalu berlangsung dalam konteks pengalaman sosial, dan hakikat serta isi pengalaman sosial itu, secara logis maupun psikologis, mendahului penngalaman murni bersifat personal.

Dengan begitu, maka seluruh pengalaman personal sejalan dengan (atau cocok dengan) rumusan sosial mengenai kenyataan (rumus itu sudah ada lebih dulu dan sudah mendominasi).(inilah landasan relatifisme budaya). Tokoh ideologi pendidikan liberal ini diwakili oleh John Dewey. ${ }^{9}$

e. Ideologi Pendidikan Liberasionisme

Dalam pandangan William F. O’Neill tentang ideologi pendidikan liberasionisme, dimana sasaran puncak pendidikan berupa penanaman pembangunan kembali masyarakat mengikuti alur yang benar-benar berkemanusiaan (humanistik), menekankan perkembangan sepenuhnya dari potensi-potensi khas setiap orang sebagai makhluk manusia. Ini hanya bisa berlangsung di dalam kerangka kerja sebuah sistem sosial yang berkomitmen terhadap pengungkapan maksimum kebebasan-kebebasan kewarganegaraan individual dengan sebuah proses demokratis yang stabil dan tahan lama.

${ }^{8}$ William F. O’Neil. “Ideologi-Ideologi Pendidikan”...,333.

${ }^{9}$ William F. O'Neil. “Ideologi-Ideologi Pendidikan”..., 356. 
Jurnal Ilmiah "Kreatif" Vol. 18 No. 1, Januari 2020 "Jurnal Studi Pemikiran Pendidikan Agama Islam"

Lebih khusus lagi, sekolah mesti menyediakan informasi serta ketrampilan bagi para siswa supaya mereka bisa belajar secara efektif bagi mereka sendiri. Sekolah harus mengajarkan bagaimana caranya menyelesaikan persoalan-persoalan praktis, melalui penerapan teknikteknik pemecahan masalah secara individual maupun kelompok, yang didasarkan pada pembuktian pengetahuan secara ilmiah-rasional. Sekolah harus membantu para siswa untuk mengenali dan menanggapi kebutuhan bagi pembaharuanatau perombakan apa pun yang tampaknya merupaka tuntutan zaman. Tokoh-tokoh gerakan ini diwakili oleh Paulo Freire dan Niel Postman. ${ }^{10}$

f. Ideologi Pendidikan Anarkisme

Bagi kaum ideologis pendidikan anarkis, individu secara deskriptif berada di bawah masyarakat (dalam arti psikologis atau developemental) karena individu ditentukan pada intinya oleh keanggotaan sosialnya. Disisi lain, individu secara deskriptif lebih tinggi kedudukannya (superior) ketimbang masyarakat (dalam arti filosofis murni), dan ia menjadi benar-benar manusia serta mencapai pewujudan diri, hanya ketika ia melampaui perintah-perintah atau keharusan-keharusan (imperatif) masyarakat terorganisir itu secara menyeluruh.

Dengan kata lain, bagi kaum anarkis, kenyataan bahwa masyakat terorganisir belakangan lebih diutamakan ketimbang ungkapan diri individual adalah tepat, namun tetap saja situasi itu pantas disesalkan, lantaran secara objektif individu mampu memantulkan perilaku moral secara langsung tanpa dipaksakan, dan perilaku semacam itu tidak butuh kekangan atau kontrol sosial dari luar. Tokoh pemikiran dari ideologi diantaranya adalah Ivan Illich dan Erich Fromm. ${ }^{11}$

\section{Hasil Penelitian}

1. Kurikulum Sebagai Media Penanaman Nilai Keislaman

Menurut Nana Syaodih Sukmadinata mengatakan bahwa kurikulum merupakan suatu rencana yang memberi pedoman atau

\footnotetext{
${ }^{10}$ William F. O’Neil. “Ideologi-Ideologi Pendidikan..., 466.

${ }^{11}$ Ibid., 482-484.
} 
Jurnal Ilmiah "Kreatif" Vol. 18 No. 1, Januari 2020 "Jurnal Studi Pemikiran Pendidikan Agama Islam"

pegangan dalam proses kegiatan mengajar. ${ }^{12}$ Kurikulum merupakan perihal yang paling urgen dalam pelaksanaan pembelajaran di sekolah. Kurikulum menjadi pokok landasan yang didalamnya terdapat role dan tujuan dari pembelajaran. Mengingat pentingnya fungsi kurikulum, dapat dipetakan dalam 3 (tiga) konsep dasar.

Pertama, kurikulum sebagai suatu substansi. Suatu kurikulum dipandang orang sebagai suatu rencana kegiatan belajar bagi peserta didik di sekolah, atau sebagai suatu perangkat tujuan yang ingin dicapai. Suatu kurikulum juga dapat menunjuk kepada suatu dokumen yang berisi rumusan tentang tujuan, bahan ajar, kegiatan belajar mengajar, jadwal, dan evaluasi. Suatu kurikulum juga dapat digambarkan sebagai dokumen tertulis sebagai hasil persetujuan bersama antara penyusun kurikulum dan pemegang kebijakan pendidikan dengan masyarakat. Suatu kurikulum juga dapat mencakup lingkup tertentu, suatu sekolah, suatu kabupaten, provinsi, ataupu seluruh negara.

Kedua, kurikulum sebagai suatu sistem. Sistem kurikulum merupakan bagian dari sistem persekolahan, bahkan sistem masyarakat. Suatu sistem kurikulum mencakup struktur persoalan, dan prosedur kerja bagaimana cara menyempurnakannya. Hasil dari suatu sistem kurikulum adalah tersusunnya suatu kurikulum, dan fungsi dari sistem kurikulum adalah bagaimana memelihara kurikulum agar tetap dinamis.

Ketiga, kurikulum sebagai suatu bidang studi yaitu bidang studi kurikulum. Ini merupakan bidang kajian para ahli kurikulum dan ahli pendidikan dan pengajaran. Tujuan kurikulum sebagai bidang studi adalah mengembangkan ilmu tentang kurikulum dan sistem kurikulum. $^{13}$

Kurikulum adalah suatu program pendidikan yang disediakan untuk membelajarkan siswa. Dengan program itu para siswa melakukan berbagai kegiatan belajar, sehingga terjadi perubahan dan perkembangan tingkah laku siswa, sesuai dengan tujuan pendidikan

\footnotetext{
${ }^{12}$ Ibid., 28

${ }^{13}$ Siti FujiawatiFuja, "Pemahaman Konsep Kurikulum Dan Pembelajaran Dengan Peta Konsep Bagi Mahasiswa Pendidikan Seni”, (Jurnal Pendidikan dan Kajian Seni, vol. 1, April 2016), 16-28.
} 
Jurnal Ilmiah "Kreatif" Vol. 18 No. 1, Januari 2020 "Jurnal Studi Pemikiran Pendidikan Agama Islam"

dan pembelajaran.Dengan kata lain, sekolah menyediakan lingkungan bagi siswa yang memberikan kesempatan belajar. Itu sebabnya, suatu kurikulum harus disusun sedemikian rupa agar maksud tersebut dapat tercapai.UU No. 20 Tahun 2003 pasal 1 ayat (19), konsitusi menyatakan bahwa Kurikulum merupakan seperangkat rencana dan pengaturan mengenai tujuan, isi,dan bahan pelajar serta cara yang digunakan sebagai pedomanpenyelenggaraan kegiatan pembelajaran untuk mencapaitujuan pendidikan tertentu.

Kurikulum yang diterapkan di SDIT Imam Syafi'iy Kota Bima, menerapkan dua kurikulum yaitu kurikulum Pendidikan dari pemerintah dan kurikulum Pendidikan pondok. Dalam konteks kurikulum pendidikan di pondok pesantren seperti yang diungkapkan oleh Nurcholis Madjid bahwa istilah kurikulum tidak terkenal di dunia pesantren (masa pra kemerdekaan), walaupun sebenarnya materi pendidikan sudah ada didalam pesantren, terutama pada praktek pengajran bimbingan rohani dan latihan kecakapan hidup di pesantren. Oleh karena itu, kebanyakan pesantren tidak merumuskan dasar dan tujuan pesantren secara eksplisit atau mengimplementasikannya dalam kurikulum. ${ }^{14}$

Berasarkan wawancara dengan Kepala Sekolah di SDIT Imam Syafi'iy Kota Bima, menyatakan bahwa kurikulum yang digunakan SDIT Imam Syafi'iy dalam kegiatan mengajar belajar tediri dari dua kurikulum, yaitu kurikulum dari Dinas Pendidikan Pemuda dan Olah Raga dan kurikulum pendidikan Pondok. ${ }^{15}$ Penggunaan kurikulum dari Dinas DIKPORA merupakan keharusan karena keberadaan SDIT Imam Syafi'iy dibawah naungan Dikpora, sehingga kurikulum yang digunakan juga harus mengikuti kurikulum yang telah ditetapkan oleh Dikpora. Disamping itu, menurut Kepala Sekolah penerapan kurikulum pesantren dipandang perlu, karena keberadaan SDIT Imam Syafi'iy di lingkungan Pondok Pesantren Imam Syafi'iy. Hal ini merupakan salah satu upaya untuk membuat perbedaan atau ciri khas sehingga SDIT Imam Syafi'iy mempunyai nilai lebih di mata

\footnotetext{
${ }^{14}$ Kholid Junaidin, "Sistem Pendidikan Pondok Pesantren di Indonesia”,,(Jurnal Pendidikan Islam, volume 2, nomor 1, Juli-Desember 2016). 103

${ }^{15}$ Ismail Abdullah, "Wawancara", tanggal 2 Agustus 2018 (Kepala Sekolah SDIT Imam Syafi’iy Kota Bima)
} 
Jurnal Ilmiah "Kreatif” Vol. 18 No. 1, Januari 2020 "Jurnal Studi Pemikiran Pendidikan Agama Islam"

masyarakat. Penerapan kurikulum pondok juga merupakan upaya menanamkan nilai-nilai Islami kepada anak sehingga sejak dini dapat terbentuk karakter Qur'ani yang berperilaku sesuai dengan akhlak para shalafussholih sesuai dengan tujuan pendidikan di lingkungan pesantren Imam Syafi'iy. ${ }^{16}$

Table 01

Daftar Matapelajaran SDIT Imam Syafi'iy Kota Bima

\begin{tabular}{|c|l|l|}
\hline NO. & $\begin{array}{l}\text { KURIKULUM } \\
\text { PONDOK }\end{array}$ & $\begin{array}{l}\text { KURIKULUM DENDIDIKAN PEMUDA DAN } \\
\text { OLAH RAGA }\end{array}$ \\
\cline { 2 - 3 } & Mata Pelajaran & Mata Pelajaran \\
\hline 1. & Fiqh & Ilmu Pengetahuan Alam \\
\hline 2. & Aqidah & Ilmu Pengetahuan Sosial \\
\hline 3. & Tahfidzul Hadits & Bahasa indonesia \\
\hline 4. & Tahfidzul Qur'an & PJOK \\
\hline 5. & Bahasa Arab & Matematika \\
\hline 6. & Adab dan Do'a & PKN \\
\hline 7. & Shiroh & \\
\hline
\end{tabular}

2. Penguatan Aqidah Keislaman

Dalam ajaran Islam aqidah merupakan landasan yang mendasari seluruh aktivitas kehidupan Islami, sedangkan pelakunya disebut mukmin. Suatu perilaku yang tidak berangkat dari landasan itu, maka perilaku itu diluar sistem Islam atau kufur dan pelakunya disebut kafir. Sistem keyakinan dalam ajaran Islam dibangun dalam enam landasan atau yang lazim disebut rukun iman. ${ }^{17}$

Penguatan aqidah keislaman yang ditanamkan pada siswa di SDIT Imam Syafi'iy Kota Bima. Penguatan aqidah keislaman pada peserta didik dilakukan dalam kelas pada saat proses pembelajaran berlangsung karena aqidah keislaman ini termasuk matapelajaran yang diajarkan di SDIT Imam Syafi'iy, selain penguatan aqidah keislaman dalam kelas pada saat proses pembelajaran, juga dilakukan penguatan di luar kelas yaitu kegiatan ekstrakurikuler.Kegiatan ekstrakurikuler yang di lakukan di SDIT Imam Syafi'iy dalam pengutan aqidah keilaman yaitu murojaah, peserta didik murojaah kembali tentang materi-materi yang diajar setelah Dzhur peserta

\footnotetext{
${ }^{16}$ Ibid

${ }^{17}$ Ibid, 28.
} 
Jurnal Ilmiah "Kreatif" Vol. 18 No. 1, Januari 2020 "Jurnal Studi Pemikiran Pendidikan Agama Islam"

didik maju satu persatu di depan, kegiatan murojaah ini dilakukan menguatkan dan memantapkan ingatan peserta didik tentang materimateri yang diajarkan. Buku sebagai referensi yang digunakan dalam pengajaran tentang aqidah menggunakan buku adab dan akhlak buku yang diterbitkan oleh penerbit Atuqo.

Dalam pengajaran aqidah di SDIT Imam Syafi'iy tidak menggunakan kitab tertentu atau kitab khusus sebagai referensi atau rujukan, karena pembelajaran aqidah di SDIT Imam Syafi'iy hanya secara umum saja, pembahasan tentang kitab khusus sebgai bahan referensi atau rujukan itu dilakukan di tingkat SMP dan SMA saja, dan metode pembelajaran yang digunakan dalam mengajar di SDIT Imam Syafi'iy menggunakan metode tanya jawab dan metode diskusi, metode yang sering digunakan adalah metode diskusi.

Kegiatan penguatan tentang Aqidah yang dilakukan di SDIT Imam Syafi'iy yaitu peserta diajarkan teorinya tentang bagaiman tata cara sholat yang benar sesuai dengan hukum syar'i, mulai dari tata cara mengambil air wudhuh, tata cara sholat mulai dari takbir sampai salam. Setelah diajarkan tentang teorinya tahap selanjutnya diperaktekan satu-persatu di masjid pondok. Sebelum pulang peserta didik melaksanakan sholat dzhur dan ashar secara berjama'ah bersama ustadz dan ustadzah di masjid pondok.

Di dalam kelas pada mata pelajaran Adab dan Do'a, peserta didik diajarkan tentang bagaimana berpakaian yang syar'i sesuai dengan tuntunan Rasulullah SAW, perbedaan tata cara berpakaian laki-laki dan tata cara berpakaian yang perempuan, serta batas aurat laki-laki yang boleh di perlihatkan dan batas aurat perempuan yang boleh diperlihatkan. Disamping itu dan diajarkan juga bagaimana pakaian yang menutup auarat dan pakaiyan yang tidak menutup aurat.

Selanjutnya ustadz dan ustadzah menganjurkan kepada peserta didik diwajibkan memakai pakaian yang syar'i sebagai bentuk praktik dari matapelajaran yang telah diajarkan. Bagi peserta didik yang laki-laki diwajibkan memakai baju koko atau kemeja lengan panjang (Jubah) dan mekai celana yang panjang sampai di atas mata yang tidak ketat atau yang memperlihatkan bentuk tubuh. Bagi peserta didik yang perpuan diwajibkan memakai jilbab panjang yang 
Jurnal Ilmiah "Kreatif" Vol. 18 No. 1, Januari 2020 "Jurnal Studi Pemikiran Pendidikan Agama Islam"

tebal dan memakai baju yang lengan panjang (gamis). Adapula dari beberapa siswa perempuan yang memakai cadar. Pakaian semacam ini diwajibkan bagi peserta didik di SDIT Imam Syafi'iy pada saat sekolah dan menjadi model seragam sekolah tersebut.

Secara umum kegiatan belajar mengajar di SDIT Imam Syafi'iy tetap mengedepankan pengajaran yang menggunakan metode keteladanan, hal ini terlihat dari hasil pelajaran dikelas yang langsung dipraktikkan oleh siswa. Nilai-nilai agama yang ditanamkan dipercaya menjadi salah satu bentuk mengokohkan akidah keislaman siswa. Upaya penanaman nilai tersebut tidak hanya dilakukan secara formal dikelas, namun juga pada kegiatan tidak terstruktur diluar kelas, dengan mengedepankan keteladanan dari para ustadz dan ustadzah. Berdasarkan pengamatan penulis, referensi yang digunakan oleh ustadz dan ustadzah mengacu pada berbagai macam mazhab, dalam arti tidak hanya terpusat pada salah satu mazhab tertentu saja.

3. Penanaman Nilai dan Proses Pembentukan Kebiasaan/Akhlak yang Baik.

Peserta didik dibiasakan tidak boleh berkata kasar atau kotor kepada orang-orang di lingkungan sekolah atau di sekelilingnya dalam kehidupan sehari-hari, komunikasi atau interaksi siswa dengan guru di sekolah berjalan seperti biasanya diamana peserta didik menghormati ustadz sebagai pendidik sekaligus sebagai orang tua yang mendidik dan mengajarnya, guru menyayangi peserta didik sebagai anak didik sekaligus sebagai anak sendiri dalam berinteraksi menggunakan kata-kata atau bahasa yang sopan.

Penanaman nilai sikap jujur dan tidak berbohong pada peserta didik di SDIT Imam Syafi'iy agar peserta didik dalam melakukan aktivitas sehari-hari harus selalu bersikap jujur dan tidak berbohong semua aktivitas yang dilakukan diniatkan kepada Allah SWT semata. Proses pembentukan kebiasaan/akhlak yang baik adalah pendidik dalam menanamkan akhlak yang baik kepada peserta didik pendidik itu sendiri yang lebih utama/awal untuk bersikap/ berprilaku baik sebagai contoh teladan yang baik, peserta didik juga disuguhkan dengan kisah-kisah /cerita-cerita orang-orang zaman dulu yang berakhlak baik dan yang berakhlak buruk, dan juga dijelaskan dengan 
Jurnal Ilmiah "Kreatif" Vol. 18 No. 1, Januari 2020 "Jurnal Studi Pemikiran Pendidikan Agama Islam"

dalil sebagai penguat baik itu dalil dari Al-Qur'an dan Hadits, agar peserta didik termotivasi untuk memperbaiki diri dan selalu berakhlak yang baik, apabila motivasi itu sudah ada dalam hati peserta didik maka dengan mudah peserta didik akan selalu berakhlak yang baik dalam kehidupan sehari-hari sesuai apa yang diharapkan.

Berdasarkan hasil penelitian di SDIT Imam Syafi'iy peserta didik diberikan motivasi dulu bagaimana motivasi itu bisa di serap oleh peserta didik. kembali lagi kepada bagaimana peserta didik ini disuguhkan dengan rasa cinta dulu, jika peserta didik sudah cinta maka sudah pasti apapun yang peserta didik sudah suka peserta didik tidak akan putus semangat dan otomatis peserta didik akan berkerja dengan rasa cinta, jika sudah ditanamkan rasa cinta, bagaimana rasa cinta kepada Allah SWT dan Rasulullah-Nya maka dengan sendirinya peserta didik akan melakukan atau menunjukan kecintaan itu, tapi kalau peserta didik tidak diberi motivasi berupa menanamkan kecintaan kepada Rasulullah SAW maka dikhawatirkan dengan sendirinya akan menunjukan rasa cintanya kepada hal-hal yang tidak ada manfaatnya jadi salah satu teknik adalah selalu memberikan motivasi dengan rasa cinta. ${ }^{18}$

\section{Analisis Penerapan Ideologi Pendidikan di SDIT Imam Syafi'iy Kota Bima}

Berdasarkan uraian hasil penelitian tentang berbagai aktivitas pembelajaran di lingkungan SDIT Imam Syafi'iy Kota Bima dapat dikategorikan masuk dalam aliran ideologi pendidikan konservatif. Aliran ideologi konservatif memandang konsep pendidikan harus dibangun dari nilai-nilai agama, terutama yang berkaitan dengan tujuan menuntut ilmu dan apa saja jenis atau tipologi ilmu yang perlu dipelajari. Menurut aliran ini tujuan keagamaan menjadi tujuan utama (ultime goal) dalam pendidikan. Tokoh-tokoh klasik yang termasuk dalam aliran pendidikan Islam konservatif (Al-Muhafidz) adalah Al-Ghazali. Satu "gerbong" dengan Al-Ghazali yaitu Al-Thusi, Ibnu Sahnun, Ibn Jama'ah, Ibnu Hajar Al-Haitami dan Al-Qabisi. Dalam konteks proses pembelajaran, tokoh-tokoh aliran ini mempunyai cara dan metode

\footnotetext{
${ }^{18}$ Syahruddin, "Wawancara", tanggal 15 Agustus 2018 (Guru Pendidikan Agama Islam SDIT Imam Syafi'iy)
} 
Jurnal Ilmiah "Kreatif" Vol. 18 No. 1, Januari 2020 "Jurnal Studi Pemikiran Pendidikan Agama Islam"

tersendiri tapi secara umum mereka memiliki kesamaan, misalnya menggunakan metode mujahadah dan riyadah, pendidikan praktik kedisiplinan, pembiasaan dan penyajian dalil naqli dan aqli, serta bimbingan dan nasihat. ${ }^{19}$

Dalam pelaksanaan pendidikan di SDIT Imam Syafi'iy juga menggunakan cara dan metode yang sama seperti yang diuraikan di atas. Metode riyadhah diterapkan dalam upaya mengajarkan kepada siswa tentang ibadah praktis yang mana memerlukan latihan agar dapat melaksanakan shalat yang sesuai dengan tuntunan sunah Rasul. Demikian pula metode mujahadah, pembiasaan dan praktik kedisiplinan. Hal ini dapat ditemukan pada proses pembelajaran yang mewajibkan siswa untuk menghafal hadis dan ayat-ayat pendek guna untuk menanamkan pengetahuan awal tanpa perlu memastikan siswa tersebut mampu memahami maksud dari ayat atau hadis tersebut.

Dalam menggunakan media/alat pengajaran, ideologi pendidikan konservatif menyetujui adanya pujian dan hukuman, di samping keharusan menciptakan kondisi yang mendukung terwujudnya akhlak yang mulia. Aliran ini memandang segala sesuatu dari perspektif keagamaan. Dalam membicarakan tentang ilmu dan pendidikan, aliran ini cenderung normatif dan bersifat murni keagamaan. Dikarenakan menafsirkan realitas jagad raya berpangkal dari ajaran agama maka semua yang menyangkut tujuan belajar, pembagian ilmu, etika guru dan murid dan komponen pendidikan lainnya harus berpangkal dari ajaran agama. Tujuan keagamaan adalah sebagai tujuan belajar. Aliran ini juga mempersempit ruang gerak ilmu karena mengatakan bahwa ilmu yang wajib dipelajari hanyalah ilmu yang berorientasi dan bermanfaat terhadap kehidupan akhirat. ${ }^{20}$

Penghargaan dan hukuman (reward and punishment) merupakan hal yang lumrah dalam aliran pendidikan konservatif. Demikian pula yang diterapkan di SDIT Imam Syafi'iy. Ustadz dan ustadzah akan memberikan hukuman kepada siswa jika tidak sesuai dengan yang dikehendaki. Misalnya apabila siswa tidak berbicara atau bertutur

\footnotetext{
${ }^{19}$ Nur Asyiah, “Ideologi Dalam Pendidikan Islam”,(Jurnal Islamika, Volume 13 Nomor 2 Tahun 2013). 125-132

${ }^{20}$ Nur Asyiah, "Ideologi Dalam Pendidikan Islam”, (Jurnal Islamika, Volume 13 Nomor 2 Tahun 2013). 125-132
} 
Jurnal Ilmiah "Kreatif" Vol. 18 No. 1, Januari 2020 "Jurnal Studi Pemikiran Pendidikan Agama Islam"

dengan sopan, juga apabila siswa tidak berpakaian sesuai dengan syariat Islam yang baik (gamis/jubah) akan diberikan hukuman langsung dan dilayangkan surat teguran kepada orang orang tuanya. Dalam pengakuan Ustadz dan Ustadzah, hal ini menjadi komitmen SDIT Imam Syafi'iy dalam menjaga akhlak siswa agar tetap dalam bingkai syariat Islam yang benar.

Dalam perspektif ideologi pendidikan, penerapan salah satu ideologi akan memengaruhi visi dan misi lembaga pendidikan tersebut, kurikulum yang digunakan, metode pembelajaran, dan pengelelolaan kelembagaansecara umum. Sehingga hal ini juga akan berpengaruh juga pada hasil atau output dari sekolah tersebut. Seperti dipahami, pendidikan merupakan upaya untuk mengembangkan potensi peserta didik secara aktif untuk memiliki kekuatan spiritual keagamaan, pengendalian diri dan kepribadian yang baik. Ideologi pendidikan konservatif menghendaki untuk tetap kembali menghidupkan tradisi nilai-nilai yang kuat (mengakar) pada siswa, sebagai upaya untuk tetap memperkuat karakter siswa dalam menghadapi berbagai macam tantangan perubahan zaman.

Menurut Giroux dan Aronowitz, konservatif dibangun berdasarkan keyakinan bahwa peserta didik tidak merencanakan perubahan atau tidak mempengaruhi perubahan sosial. Dengan pandangan seperti itu, sekolah yang menggunakan paradigma ideologi pendidikan konservatif menganggap peserta didik tidak memiliki kekuatan atau kekuasaan untuk melakukan perubahan atas kondisi mereka. ${ }^{21}$

Ideologi konservatif mengemukakan pendidikan adalah sebagai wadah pembentukan terhadap pribadi anak tanpa memperhatikan kekuatan atau potensi anak. Dalam arti pendidikan merupakan suatu proses pembentukan jiwa dari luar dimana matapelajaran telah ditentukan menurut kemauan guru, sehingga anak tinggal menerima saja. Oleh karena itu, jika mengacu pada three law of stages menurut Auguste Comte, pendidikan dengan ideologi konservatif ini memiliki kesadaran yang berada pada tipe kesadaran magis. Dimana setiap individu dipandang sebagai makhluk statis dan tidak memiliki kebebasan dalam

${ }^{21}$ Zahra Idris, Dasar-Dasar Kependidikan, (Padang: Angkasa Raya, 2001), 9. 
Jurnal Ilmiah "Kreatif" Vol. 18 No. 1, Januari 2020

"Jurnal Studi Pemikiran Pendidikan Agama Islam"

berekspresi. $^{22}$ Sehubungan dengan ini, di SDIT Imam Syafi'iy dapat dilihat dalam praktik pembelajarannya tertuang dalam metode-metode menghafal (tahfizd), membaca (qiraah), menerjemahkan (tarjamah), mendengar (istima') dan sebagainya. Kegiatan pembelajaran yang cenderung menempatkan ustazd sebagai subjek utama dalam hal belajarmengajar. Sehingga hal ini menjadikan siswa sebagai objek yang statis dan wajib tunduk pada apapun yang didesain oleh ustadz. Dengan demikian, pendidikan dalam pandangan ideologi konservatif merupakan proses penerimaan dan tidak mengarah pada perubahan dan progresifitas. Hal ini juga sejalan dengan pendapatnya Jhon Dewey bahwasanya pendidikan konservatif merupakan proses pembentukan kepribadian anak dengan mengesampingkan kemampuan IQ anak.

Berdasarkan analisis diatas, di SDIT Imam Syafi'iy ideologi pendidikan konservatif ini mengarah pada konservatisme religius yang menekankan peran sentral pelatihan spiritual kejiwaan sebagai landasan penguatan karakter moral keislaman. SDIT Imam Syafi'iy sebagai penyelenggara pendidikan dengan idelogi konservatif ini memiliki peran dan tanggungjawab untuk menanamkan kepada siswa sebagai generasi muda tentang nilai-nilai akidah keislaman yang baik sehingga dapat berpengaruh pada tingkah laku dan kehidupan sosialnya di masyarakat.

\section{Penutup}

Dari uraian di atas, penelitian ini dapat disimpulkan sebagai berikut.

1. Nilai-nilai Keislaman yang Ditanamkan di SDIT Imam Syafi'iy Kota Bima, meliputi: Nilai Aqidah, Peserta didik diajarkan pokok-pokok keimanan dalam ajaran Islam menyangkut Tauhid tentang keyakinan terhadap Allah SWT; keteladanan kepada Nabi Muhammad Saw; nilai kejujuran; nilai keteladanan; dan nilai Ibadah.

2. Ideologi pendidikan yang digunakan dalam menanamkan nilai-nilai keislaman di SDIT Imam Syafi'iy Kota Bima, adalah menggunakan ideologi pendidikan konservatisme. Ideologi pendidikan konservatisme ini memengaruhi proses pelaksanaan pembelajaran di

${ }^{22}$ Uyoh Sadullah, Pengantar Filsafat Pendidikan, (Bandung: Alfabeta, 2009), 124 
Jurnal Ilmiah "Kreatif" Vol. 18 No. 1, Januari 2020

"Jurnal Studi Pemikiran Pendidikan Agama Islam"

SDIT Imam Syafi'iy Kota Bima, ideologi ini mengarahkan siswa hanya menjadi objek dan ustadz/guru melakukan pembelajaran tanpa melihat kebutuhan dan kemampuan siswa secara detail.

\section{DAFTAR PUSTAKA}

Fuja Siti Fujiawati, "Pemahaman Konsep Kurikulum Dan Pembelajaran Dengan Peta Konsep Bagi Mahasiswa Pendidikan Seni”, Jurnal Pendidikan dan Kajian Seni, vol. 1, April 2016.

H.A.R. Tilaar. "Kekuasaan dan Pendidikan Suatu Tinjauan dar Perspektif Studi Kultural”, Magelang: IndonesiaTera. 2003.

Kholid Junaidin, "Sistem Pendidikan Pondok Pesantren di Indonesia", Jurnal Pendidikan Islam, volume 2, nomor 1, Juli-Desember 2016.

John B Thomson, "Analisis Ideologi Kritik Wacana Ideologi-ideologi Dunia”, Penerjemah Haqqul Yaqin. Yogyakarta: IRCiSoD. 2007.

Nur Asyiah, "Ideologi Dalam Pendidikan Islam”, Jurnal Islamika, Volume 13 Nomor 2 Tahun 2013.

Suroso Abdussalam, "Sistem Pendidikan Islam", Bekasi: sukses Publishing, 2011.

Uyoh Sadullah, Pengantar Filsafat Pendidikan, Bandung: Alfabeta, 2009.

William F. O’Neil. “Ideologi-Ideologi Pendidikan", alih bahasa Omin Intan Naomi. Yogyakarta: Pustaka Pelajar. 2002.

Zahra Idris, Dasar-Dasar Kependidikan, Padang: Angkasa Raya, 2001. 